\title{
A Study of Creativity In Relation To Big 5 Personality Traits
}

\author{
Dr. Thiyam Kiran Singh $^{1 *}$, Sakshi Kaushik ${ }^{2}$
}

\section{ABSTRACT}

The study of personality is one of the oldest areas in the science of creativity. Creative people combine playfulness and discipline or responsibility and irresponsibility. Creativity has been acknowledged as one of the most predominant factors contributing to individual performance in various domains of work and both researchers and practitioners have been devoting increasing attention to creative performance. Thus, the present investigation aimed at studying creativity in relation to Big 5 Personality Traits. The sample comprised of 40 artists (20 performing artists and 20 non-performing artists) between 25-35 years of age. For this purpose Big Five Inventory (BFI) developed by John and Srivastava (1999) was used to assess the domains of: Openness, Conscientiousness, Extraversion, Agreeableness and Neuroticism. Creativity was assessed by using the relevant items for the virtue of Creativity from the Values in Action Inventory of Strengths Scale (VIA-IS) developed by Peterson, Park, \& Seligman (2005). To achieve the objectives of the study, inter correlations and t-ratios were calculated. The results found significant correlation ship between creativity and extraversion showing that more creative artists expressed more extraversion than the less creative ones. Also, there were no significant difference between performing and non-performing artists in creativity and the big 5 personality traits.

Keywords: Artists, Creativity, Personality Traits, Big-5.

Creativity is a phenomenon whereby something new and somehow valuable is formed, such as an idea, a scientific theory, an invention, a literary work, a painting, a musical composition, a joke, etc. The lexeme in the English word creativity comes from the Latin term creō, "to create, make": its derivational suffixes also come from Latin. The word "create" appeared in English as early as the 14th century, notably in Chaucer, to indicate divine creation (in The Parson's Tale). However, its modern meaning as an act of human creation did not emerge until after the Enlightenment. Scholarly interest in creativity involves many definitions and concepts pertaining to a number of disciplines: psychology, cognitive science, education, philosophy (particularly philosophy of science), technology, theology, sociology, linguistics, business studies, songwriting, and economics, covering the relations between creativity and general intelligence,

\footnotetext{
${ }^{1}$ Associate Professor, Clinical Psychology, Government Medical College \& Hospital, Chandigarh

${ }^{2}$ M.Phil, Clinical Psychology, Trainee, Government Medical College \& Hospital, Chandigarh *Responding Author

(C) 2015 I T Singh, S Kaushik; licensee IJIP. This is an Open Access Research distributed under the terms of the Creative Commons Attribution License (http://creativecommons.org/licenses/by/2.0), which permits unrestricted use, distribution, and reproduction in any Medium, provided the original work is properly cited.
} 
mental and neurological processes, personality type and creative ability, creativity and mental health; the potential for fostering creativity through education and training, especially as augmented by technology and the application of creative resources to improve the effectiveness of teaching and learning. Theories of creativity have focused on a variety of aspects. The dominant factors are usually identified as "the four Ps" — process, product, person and place (according to Mel Rhodes). A focus on process is shown in cognitive approaches that try to describe thought mechanisms and techniques for creative thinking. Theories invoking divergent rather than convergent thinking (such as Guilford) or those describing the staging of the creative process are primarily theories of creative process. A focus on creative product usually appears in attempts to measure creativity and in creative ideas framed as successful memes. The psychometric approach to creativity reveals that it also involves the ability to produce more. A focus on the nature of the creative person considers more general intellectual habits, such as openness, levels of ideation, autonomy, expertise, exploratory behavior and so on. Creative person are more successful in life than those who are less creative. In a recent global survey, more than 1,500 corporate and public sector leaders reported that creativity is the most important quality a leader must have (Vincent and Kouchaki, 2015). In general, creative people are more open to new experiences, less conventional and less conscientious, more self-confident, selfaccepting, driven, ambitious, dominant, hostile, and impulsive (Feist, 2015). The present study will help in understanding regarding the creativity of artists and the personality traits of them so that it may help the youngsters to choose their career whether to go either for performing arts or non performing arts to become more successful in their career.

\section{METHODOLOGY}

\section{Objectives:}

1. To study the relationship between creativity and big 5 personality traits.

2. To compare creativity and personality traits of performing artists and non-performing artists.

\section{Sample:}

The sample comprised of 40 artists out of which 20 were performing artists and another 20 were non-performing artists.

\section{Inclusion Criteria:}

1. Male and Female Performing and Non Performing artists.

2. Age between 25-35 years

3. Those who can give their consent for study

\section{Exclusion Criteria:}

1. Mentally ill patient who have diagnosed by Psychiatrist. 


\section{Tools Used:}

\section{Big Five Inventory (BFI, John and Srivastava, 1999)}

The Big Five Trait Taxonomy was developed by O. P. John and S, Srivastava (1999). This scale measures an individual on the big 5 factorsof personality (Goldberg, 1993). Each of the factors is then further divided into personality facets. The Big 5 factors are: Extraversion vs. Introversion, Agreeableness vs. Antagonism, Conscientiousness vs. Lack of direction, Neuroticism vs. Emotional Stability, and Openness vs. Closedness to experience. The BFI is a 44-item self-report inventory, 5-point questionnaire. It's a 5-point rating scale which ranges from 1 (strongly disagree) to 5 (strongly agree). The internal consistency reliabilities were: mean $\alpha$ values were .77, .78, and .81 (Borroni et. al, 2011).

\section{The Value in Action Inventory Strengths Scale: (VIA-IS; Peterson, Park, \& Seligman, 2005)}

The Values in Action Inventory of Strengths consists of 240 items for the self-assessment of the 24 character strengths (10 items per strength) included in the classification of Peterson and Seligman (2004). The VIA-IS uses a 5-point Likert-style format (very much like me to very much unlike me). In the present study, participants are being assessed for one character strength, i.e. Creativity. Hence, for the virtue of creativity, the relevant item numbers are: 4, 28, 52, 76, $100,124,148,172,196$ and 220. The 24 subscales had high reliability (median $\alpha=.77$; median corrected item-total correlations $=.45$ ) and high stability across 9 months (median test-retest correlation $=.73$ ). The VIA-IS peer form also had high reliability (median $\alpha=.81)$.

\section{Procedure:}

A total sample of 40 were collected using snowball sampling methods, out of which 20 were performing artists and 20 were non performing artists. The information of artists were collected through email from some known artists and information's of rest of the unknown artists were collected through known artists. The information were gathered by using big 5 Inventory and the value in Action Inventory Strengths Scale in order to get traits of personality and creativity of them. The research was conducted at Department of Psychology, under Panjab University.

\section{Statistical Analysis:}

Statistical analysis was done with the help of Statistical Package of Social Science (SPSS-20.0). Mean and Standard Deviation were calculated followed by correlation to see the relationships of creativity and big five personality traits and t- test to compare between two groups namelyperforming artists and non-performing artists. 


\section{RESULTS}

Table 1: Shows the correlation of creativity and big 5 personality traits in the domains of Openness, Conscientiousness, Extraversion, Agreeableness and Neuroticism: (df=38)

\begin{tabular}{|l|l|l|l|l|l|}
\hline Variables & Openness & Conscientiousness & Extraversion & Agreeableness & Neuroticism \\
\hline Creativity & .0990 & .0675 & $.3845^{* *}$ & .0543 & -.0060 \\
\hline
\end{tabular}

Significant Value at $.05=.257^{*}$, Significant value at $.01=.358^{* *}$

Table shows the correlation of creativity and big 5 personality traits. The result found significant $(r=0.3854, P<0.01)$ in the domains of extraversion. This provides the impression that creativity and extraversion are positively correlated which means, with the increase of creativity extraversion of artists also increased.

Table 2: Shows the comparison of performing artists and non-performing artists in creativity and personality traits i.e. openness, conscientiousness, extraversion, agreeableness and neuroticism.

\begin{tabular}{|l|l|l|l|l|l|}
\hline \multirow{2}{*}{ Variables } & Performing Artists & \multicolumn{2}{l|}{ Non-Performing Artists } & t-ratio \\
\cline { 2 - 6 } & MEAN & SD & MEAN & SD & \\
\hline Creativity & 19.75 & 7.41 & 17.95 & 4.85 & 1.1462 \\
\hline Openness & 38.55 & 8.48 & 40.45 & 7.08 & .6845 \\
\hline Conscientiousness & 28.70 & 4.01 & 30.21 & 4.49 & .9322 \\
\hline Extraversion & 27.50 & 4.21 & 25.60 & 7.09 & .9885 \\
\hline Agreeableness & 26.45 & 4.63 & 27.70 & 4.55 & .7328 \\
\hline Neuroticism & 24.00 & 2.47 & 24.25 & 3.18 & .3001 \\
\hline
\end{tabular}

Significant value at $.05=1.729 *$, Significant value at $.01=2.539 * *$

Table shows the comparison of performing artists and non-performing artists. The result did not find any significant in creativity and also at all the domains of big 5 personality traits- openness, conscientiousness, extraversion, agreeableness and neuroticism.

\section{DISCUSSION}

The present study is to see creativity in relation with big 5 personality traits. The result found significant in the domains of extraversion. This provides the impression that creativity and extraversion are positively correlated which means, with the increase of creativity extraversion of artists also increased. This is supported by the study of Wolfradt and Pretz (2001) who found that more creative students expressed more extraversion than their less creative peers. The metaanalytical study of Batey and Furnham (2006) showed that extraversion is positively related to everyday creativity and negatively related to artistic and intellectual creativity. Extraversion appears as a positive correlate of some domains of creativity. Extraverts are likely to be more successful at creative tasks because they have a higher than average level of dopamine, the 'happiness chemical', in their brains than introverts and this chemical floods the brain at even higher doses when a person is in a good mood, according to Dr Stafford (Happy extraverts are more creative: study, 2010) 


\section{CONCLUSION:}

The present study can conclude that creativity and extraversion are positively correlated which means, with the increase of creativity extraversion of artists also increased. Performing artists and Non-performing artists required equal creativity and also have similar kind of personality traits like openness, conscientiousness, extraversion, agreeableness and neuroticism as there were no significant difference between performing and non-performing artists in creativity and the big 5 personality traits.

\section{REFERENCES:}

Batey, M. \& Furnham, A. (2006). Creativity, intelligence and personality: A critical review of the scattered literature. Genetic, Social, and General Psychology Monographs, 132, 355429.

Feist, G.J. (2015).A Meta-Analysis of Personality in Scientific and Artistic Creativity. Personality and social psychology review. Retrieved from http://psr.sagepub.com/content/2/4/290.short on 23/11/2015.

Goldberg, L. R. (1993). The structure of phenotypic personality traits. American Psychologist 48 (1), 26-34. doi:10.1037/0003-066X.48.1.26. PMID 8427480.

Happy extraverts are more creative: study. (2010). Retrieved from http://phys.org/news/2010-08happy-extraverts-creative.html on 21/11/2015

John, O. P., \& Srivastava, S. (1999). The Big-Five trait taxonomy: History, measurement, and theoretical perspectives. In L. A. Pervin \& O. P. John (Eds.), Handbook of personality: Theory and research (Vol. 2, pp. 102-138). New York: Guilford Press.

Peterson, C., Park, N., \& Seligman, M.E.P. (2005). Assessment of character strengths. In G.P. Koocher, J.C. Norcross, \& S.S.HillIII (Eds.), Psychologists’ desk reference (2n ded.,.9398). New York: Oxford University Press.

Vincent, L.C., \& Kouchaki, M. (2015). Why Creative People Are More Likely to Be Dishonest.Retrieved from https://hbr.org/2015/11/why-creative-people-are-more-likelyto-be-dishonest on 23/11/2015.

Wolfradt, U., \& Pretz , J.E. (2001).Individual differences in creativity: personality, story writing, and hobbies. European Journal of Personality, 15(4), 297-310. 